\title{
Trabalho Análogo ao Escravo e o Limite da Relação de emprego: Natureza e Disputa na Regulação do Estado
}

Vitor Araújo Filgueiras ${ }^{1}$

Nas últimas décadas, um dos fenômenos do chamado mundo do trabalho que tem obtido mais destaque na sociedade brasileira, inclusive nos meios de comunicação, é o trabalho análogo ao escravo. A despeito dos muitos casos de resgates de trabalhadores divulgados no Brasil, normalmente não fica claro, especialmente nas reportagens veiculadas na mídia, sobre o que exatamente está se tratando. Mas essa penumbra atinge também a literatura sobre o tema. Não por acaso, são utilizadas diferentes designações para o fenômeno, como trabalho escravo, trabalho degradante, servidão por dívida, trabalho escravo contemporâneo, dentre outras².

É com base na confusão (frequentemente proposital) entre trabalho escravo e trabalho análogo ao escravo que as forças dominantes, sejam capitalistas ou agentes do Estado que os representam, atacam recorrentemente a colocação de limites à exploração do trabalho. Em alguns casos, fala-se simplesmente que não há trabalho escravo no Brasil (ver entrevistas em OIT (2011)). Mais recorrentemente, contudo, os ataques são canalizados à legislação brasileira, criticando o conceito de trabalho análogo ao escravo, em particular sua caracterização pelo trabalho degradante e jornada exaustiva contida no código penal.

\footnotetext{
${ }^{1}$ Universidade Estadual de Campinas / Ministério do Trabalho (auditor fiscal); doutor em Ciências Sociais, pósdoutorando em desenvolvimento econômico.

${ }^{2}$ Diversas nomenclaturas adotadas pela literatura podem ser encontradas em Ribeiro Silva (2010).
}

Brasiliana - Journal for Brazilian Studies. Vol. 2, n.2 (Nov 2013). ISSN 2245-4373. 
Devido a ausência de critérios objetivos legais para caracterizar o trabalho escravo, associados a outros conceitos subjetivos de trabalho degradante e jornada exaustiva, empresas sérias têm sido injustamente punidas e expostas publicamente, com impactos relevantes na sua imagem e sobrevivência (CNI, 2012, p.84)

Trata-se de recente documento da Confederação Nacional da Indústria. Mesmo expresidentes do Supremo Tribunal Federal (STF) e do Tribunal Superior do Trabalho (TST) repetem a alegação de que a legislação seria subjetiva (veremos tais manifestações ao longo do texto). O que está por trás dessas investidas, contudo, é o anseio de restringir a limitação da exploração do trabalho apenas à coerção individual direta do capitalista sobre o trabalhador. Isso fica evidente no supracitado documento da CNI, que propõe a: "explicitação das condições que caracterizam o trabalho escravo ou análogo ao escravo a partir da delimitação do cerceamento efetivo da liberdade e não remuneração".

O objetivo principal deste artigo é indicar como o trabalho análogo ao escravo (ou outra designação que seja dada ao fenômeno, apesar de não acharmos adequadas, conforme veremos no decorrer do texto) se constituiu em um conceito de imposição de limite ao assalariamento, especificamente, à relação de emprego, no Brasil, nas últimas décadas. Nesse percurso, veremos as principais características do fenômeno e da sua regulação. A análise será permeada pelas histórias de Jeferson e Janine, jovens de 15 e 14 anos de vida, respectivamente, que ilustram paradigmaticamente a natureza e os limites (se mensuráveis) inerentes à relação de emprego sob a lógica do capital.

Complementarmente, ampliando o escopo da análise, são utilizados dados agregados sobre o trabalho análogo ao escravo no país. A principal fonte são os resultados globais das fiscalizações do Ministério do Trabalho (MTE) desde 1995, que contemplam diversas informações sobre o tema. Também foram investigados dados provenientes do 
Ministério Público Federal (MPF), Ministério Público do Trabalho (MPT), Comissão

Pastoral da Terra (CPT). Além disso, houve consulta à jurisprudência da Justiça do Trabalho (JT), Justiça Federal (JF), Superior Tribunal de Justiça (STJ), Supremo Tribunal Federal (STF), depoimentos e reportagens sobre casos de trabalho análogo ao escravo.

\section{Relação sem limites}

Conheci Jeferson e Janine em $2009^{3}$. Estes jovens não se conhecem e moram a milhares de quilômetros de distância que separam Pará e Santa Catarina. Eles aparentemente têm pouco em comum, como o senso comum pode especular que Pará e Santa Catarina em nada se assemelham. Entretanto, Jeferson e Janine estão muito próximos, assim como Pará e Santa Catarina não estão tão distantes. O que os aproxima? Os jovens eram parte de uma mesma relação social, estando inseridos subordinadamente nessa relação. Mais especificamente, a relação que os subsumia ultrapassou o limite permitido para que fosse socialmente legitimável. Jeferson e Janine eram trabalhadores submetidos à condição análoga à de escravos, o limite da relação de assalariamento no Brasil.A questão é: tem limite essa relação?

O assalariamento se institui historicamente a partir da dupla liberdade que a parcela majoritária da população que trabalha passa a gozar em determinada sociedade. Por um lado, livre dos laços de dependência específicos de outros modos de produção (como a condição de servo ou escravo); por outro, "livre" do controle sobre os meios de produção. Essa dupla liberdade tem como corolário, para a população que trabalha, um destino compulsório, qual seja, a venda de sua força de trabalho como meio para sua reprodução (inclusive física). Os compradores da força de trabalho são os proprietários

\footnotetext{
${ }^{3}$ Com exceção dos nomes, todos os dados apresentados sobre Jeferson e Janine correspondem estritamente aos fatos detectados em duas operações do Grupo Especial de Fiscalização Móvel (GEFM) do Ministério do Trabalho.
}

Brasiliana - Journal for Brazilian Studies. Vol. 2, n.2 (Nov 2013). ISSN 2245-4373. 
dos meios de produção, cujo objetivo no bojo de tal relação social é a obtenção incremental do excedente socialmente produzido, que nesta sociedade ganha a forma de lucro monetário.

A busca do lucro como objetivo do capital é um dos fenômenos mais estilizados da história das ciências sociais, sobre o qual concordam desde os clássicos Marx (2002) ${ }^{4} \mathrm{e}$ Weber (2003), até a teoria econômica ortodoxa. Seja por personificar o capital, pela ação racional ou pelo hedonismo inerente ao ser humano, concorda-se que o capitalista tem como objetivo a busca do lucro sempre renovado.

Contudo, a busca pelo lucro não é efetuada pelo capitalista apenas regularmente, mas também compulsivamente, conforme qualifica Weber (2003, p. 94, p. 99). Para o autor, a ação capitalista tende a desvincular-se dos meios que inicialmente a justificam, engendrando uma ação com fim em si mesma ${ }^{5}$. Mais do que desvincular-se dos fins, constituindo-se em autojustificação, a história do capitalismo abunda indícios de apartamento entre os meios socialmente estabelecidos para a obtenção do lucro pelo capital e a busca efetivamente empreendida pelo mesmo. Assim, a ação capitalista não apenas tende a se autonomizar enquanto fim, conforme argumenta Weber (2003), mas também a se descolar dos meios que não aqueles que corroborem sua reprodução ${ }^{6}$. Partindo de outro corte epistemológico, Marx (2002) demonstra fartamente como opera

\footnotetext{
4 "Enquanto a apropriação crescente da riqueza abstrata for o único motivo que determina suas operações, funcionará ele como capitalista, ou como capital personificado, dotado de vontade e consciência" (2002, p.183). Em que pese não ser este o espaço para esmiuçar a questão, me parece contraproducente a enorme celeuma historicamente incrustada no marxismo assentada na falsa dicotomia entre motivação e determinação para buscar o lucro, que discrimina artificialmente supostos fatores objetivos e subjetivos na explicação da reprodução do capital. A rigor, ambas as perspectivas fetichizam a natureza da relação social.

${ }^{5}$ A vocação ao trabalho, da poupança e reinversão, etc., oriundos dos valores religiosos, motivam os indivíduos para a ação capitalista, tendo como fim a salvação. Contudo, o autor percebe que a ação capitalista tende a se desvincular da sua motivação religiosa, se constituindo em um fim em si mesmo. É desfeito o elo com o mundo: o capitalismo, segundo Weber (2003, p.99), não carece mais do suporte do asceticismo religioso, constituindo uma convulsiva espécie de autojustificação.

${ }^{6}$ Após o quase cataclisma do mundo e posterior tentativa de domesticação da chamada Era Fordista, o capital tem reagido intensivamente para superar elementos que obstaculizam sua "livre" reprodução.
}

Brasiliana - Journal for Brazilian Studies. Vol. 2, n.2 (Nov 2013). ISSN 2245-4373. 
a compulsão do capital pela sua reprodução incremental, que questiona limites morais, geográficos, culturais e jurídicos estabelecidos antes ou mesmo durante a disseminação e estabelecimento dessa relação social. Na teoria econômica ortodoxa, a busca pelo lucro deriva da característica imanente (natural) do homem de maximizar seus benefícios e minimizar esforços, apresentando o mercado como ente trans-histórico ideal para realização do hedonismo, cujas resistências artificiais eventualmente imputadas são natural e necessariamente superadas pelo cálculo custo-benefício.

Como o lucro é extraído do trabalho, este é vítima necessária e preferencial das ofensivas do capital sobre os meios indesejados à sua reprodução. Destarte, atributos indesejáveis à reprodução do capital, que acompanhem o trabalho, são sempre atacados, desde os primórdios do capitalismo. Por exemplo, o processo de discussão, elaboração e efetivação da legislação fabril na Inglaterra do século XIX é minuciosamente analisado por Marx (2002), que demonstra como o capital lutou arduamente contra a regulação em todas as referidas etapas ${ }^{7}$.

Se por um lado o capital usa de todas as armas para extrair o máximo da riqueza social e despender o mínimo, por outro o trabalho pode se submeter a quase qualquer situação no bojo da relação, pois, conforme já indicado, depende da venda da sua força de trabalho para sobreviver. Conforme argumenta Polanyi (2000), a transformação do trabalho em mercadoria engendra a eliminação do "direito à vida".

\footnotetext{
${ }^{7}$ Não se pode confundir o ataque conta a legislação fabril contra o ataque a qualquer regulamentação. Muitas regras, em determinados contextos, podem contribuir para reprodução do capital, sendo consentidas ou mesmo demandadas por ele. O caso do direito do trabalho é paradigmático. Atacado duramente desde os seus primórdios, ele é parcialmente aceito e mesmo contribui para a reprodução do capital, conforme mostra Marx no caso do emprego das máquinas mais modernas a partir de exigências da higiene do trabalho. A formalização dos vínculos de emprego, dos controles da jornada, etc., do mesmo modo, no período fordista contribuíram para a padronização e subsunção do trabalho ao capital, sendo funcionais naquele contexto (mesmo que individualmente os capitalistas resistissem à regulamentação). Todavia, a partir do momento em que a regulação dificulta (ou simplesmente desacelera) sob qualquer modo a reprodução do capital, como agora acontece dada a hegemonia do capital financeiro e demanda por velocidade e flexibilidade da acumulação, as regras são prontamente atacadas.
}

Brasiliana - Journal for Brazilian Studies. Vol. 2, n.2 (Nov 2013). ISSN 2245-4373. 
O resultado dessa combinação é que, dada a compulsão do capital e a "liberdade" do trabalho, não há um limite inerente às condições de venda e uso da força de trabalho (à relação de assalariamento), ou seja, sem a organização coletiva do trabalho ou intervenção externa podem emergir, inclusive, padrões de uso que seriam próprios de outro modo de produção.

Jeferson e Janine trabalhavam em condição análoga à dos escravos, estatuto formalmente eliminado do quadro jurídico brasileiro no século XIX. O trabalho escravo foi política de Estado no Brasil colonial (Estado português) e assim continuou após a independência, até 1888. Este foi o modelo de relação de produção adotado para a produção do excedente sob domínio português e mantido depois da constituição de um Estado emancipado. Subsumida à lógica da reprodução ampliada da riqueza desde o início, a relação entre proprietário e escravo foi pautada pela exploração extrema do último sob diversos aspectos (condições subumanas de alimentação, moradia, higiene, segurança, saúde), inclusive da vida útil dos trabalhadores escravizados - em torno de 20 anos após a abolição do tráfico (Silva, 2008).

Mais de um século depois de cessada a propriedade formal de homem sobre homem como política de Estado, substituída pelo assalariamento através da liberdade formal dos indivíduos e monopolização dos meios de produção, abundam no Brasil flagrantes de condições de trabalho parecidas, iguais ou mesmo piores que aquelas verificadas no período de escravidão institucionalizada.

Jeferson e Janine foram vítimas de submissão a condições análogas àquelas vivenciadas pelos escravos. As informações abaixo apresentadas acerca das condições de trabalho dos dois jovens foram detectadas in loco, prescindindo de adjetivos para comparação com o escravismo anterior à lei áurea:

Jeferson trabalhava no plantio de uma lavoura de tomate, no noroeste do rico estado de Santa Catarina. O trabalho era organizado por espécies de lotes de plantação, 
ficando um grupo de trabalhadores (em geral, uma família) responsável por cada lote. As famílias eram contratadas por um intermediário, que era o dono das terras, mas totalmente financiado e subordinado ao verdadeiro empregador, um atacadista do estado de São Paulo. Os trabalhadores eram submetidos a um regime de suposta sociedade relativamente à área que cuidavam; não recebiam salário e teriam uma parcela da produção final. Os trabalhadores laboravam durante todo o ciclo produtivo, do plantio à colheita do tomate, e adquiriam seus bens de consumo num mercado com base em crédito acertado com o intermediário, que seria descontado do pagamento ao final da colheita. Desse modo, todos os trabalhadores estavam supostamente em dívida com o preposto do verdadeiro empregador a partir do momento em que se instalavam no local, não podendo deixar o estabelecimento.

Jeferson e sua família estavam inseridos nesse cenário. Ocorre que a mãe do jovem teve divergências com o intermediário e deixou a plantação. Como ela era supostamente devedora, foi obrigada a deixar o filho como forma de pagamento, ou melhor, deixou o filho para que este trabalhasse para quitar a suposta dívida, já que a força de trabalho do jovem era a única mercadoria possível de transacionar. Desse modo, Jeferson se abrigou na construção onde estava alojada outra família (que também possuía filhos menores em atividade) e trabalhava para pagar os débitos.

O estabelecimento onde Jeferson trabalhava empregava vinte trabalhadores, incluindo algumas famílias inteiras. Os trabalhadores ficaram abrigados na fazenda, em construções precárias (sem piso de material resistente ou cobertura capaz de proteger contra intempéries) próximas às respectivas áreas de plantio do tomate. A água consumida não havia passado por qualquer teste de qualidade, era marrom (literalmente), sendo oriunda de um igarapé de água quase parada próximo à plantação. Durante a jornada as refeições eram efetuadas nas frentes de trabalho, mas não havia 
qualquer espécie de abrigo, mesas ou cadeiras para uso dos empregados, nem banheiros.

A cultura do tomate é pródiga na utilização de agrotóxicos, e no empreendimento que empregava Jeferson não era diferente. Havia aplicação de diversos tipos de agrotóxicos de várias classes toxicológicas, como I e II, respectivamente extremamente e altamente tóxicos, a exemplo dos produtos Lannate e Kocide. Contudo, os trabalhadores expostos não foram capacitados sobre prevenção de acidentes com agrotóxicos; o empregador não fornecia vestimentas adequadas e por isso os trabalhadores utilizavam suas roupas de uso pessoal para aplicação dos agrotóxicos. Os próprios trabalhadores e/ou suas respectivas esposas realizavam a lavagem das vestimentas utilizadas na aplicação dos agrotóxicos, sem qualquer espécie de treinamento prévio. A higienização era efetuada nas construções que abrigavam os trabalhadores e as vestimentas utilizadas na aplicação de agrotóxicos ficavam estendidas nos varais das moradias. Não havia qualquer espécie de sinalização nas lavouras para identificar onde estava ocorrendo aplicação de agrotóxicos. Os trabalhadores laboravam sem utilização de equipamentos de proteção individual (EPI) (vestimentas adequadas, botas, luvas e óculos de proteção), pois não lhes havia sido fornecido. Alguns trabalhadores utilizavam uma embalagem de agrotóxico como recipiente para conservação e consumo de água.

Os agrotóxicos eram armazenados em edificação que se situava a menos de 30m das habitações e locais onde eram consumidos alimentos. As embalagens de agrotóxicos não estavam sobre estrados, pilhas estáveis, afastadas das paredes, nem do teto. A edificação destinada ao armazenamento de agrotóxicos não possuía placas ou cartazes com símbolos de perigo, nem tinha paredes e cobertura resistentes. Havia embalagens de diversos tipos de agrotóxicos, vazias ou em utilização, totalmente expostas ao lado da plantação. Tratava-se, inquestionavelmente, de situação de grave e iminente risco à vida 
de todos os trabalhadores submetidos àquela situação, havendo também mulheres grávidas e filhos pequenos expostos ao mesmo cenário.

Janine, no norte do país, trabalhava na atividade do roço de juquira para o pasto. Tratava-se de um braço do empreendimento do empregador, qual seja, a produção de leite. Para isso, a primeira etapa é roçar o terreno para a produção do pasto, onde é criado o gado que fornecerá o leite. A jovem não trabalhava diretamente no roço, servindo como organizadora da logística para que seus colegas trabalhassem no campo. Ela organizava os abrigos e preparava as refeições dos trabalhadores.

Janine e seus colegas estavam abrigados em dois barracos de lona. Esses barracos eram feitos com pedaços de madeira, cobertos com lona preta e palha de folhas secas e o piso dos abrigos era a própria terra batida. Os abrigos não possuíam paredes, nem forneciam qualquer proteção contra intempéries ou ataques de animais. Os trabalhadores relataram que fazia muito frio à noite. Eles dormiam em redes trazidas de suas próprias casas, que ficavam penduradas nas estacas de madeira que sustentavam os barracos. Seus pertences e alimentos ficavam espalhados pelo chão de terra batida, dentro de sacolas ou pendurados, juntamente com foices e outras ferramentas de trabalho. Os trabalhadores realizavam suas refeições sentados em toco de árvores ou no chão. Não havia água limpa para higienização, mesas, assentos, depósitos de lixo com tampas.

O preparo de alimentos ocorria em vestígios de fogões rústicos, junto ao chão ou em bancadas improvisadas, sem água limpa, sem qualquer higiene e sem condições para a manipulação, armazenamento, higienização e conservação dos alimentos e utensílios de cozinha. Não havia qualquer espécie de lavatório ou vaso sanitário. Os trabalhadores eram obrigados a realizar suas necessidades fisiológicas no mato, sem garantia de condições de higiene ou de privacidade. No local também não havia chuveiro para o banho. Os trabalhadores utilizam um igarapé de coloração escura para a higienização, 
sendo a mesma água utilizada para beber, preparar alimentos, lavar roupas e utensílios. A água quase parada, que não recebia nenhum tipo de tratamento, era concomitantemente utilizada por trabalhadores e pelo gado da fazenda. Não foram apresentados quaisquer atestados de potabilidade da água e, segundo declaração dos trabalhadores, a água tinha um gosto muito ruim.

Os trabalhadores foram admitidos sem que fossem submetidos a exame médico admissional e não haviam recebido salário mesmo depois de mais de 2 meses de atividade. O empregador não forneceu aos trabalhadores EPI, tais como luvas, botinas e chapéus. Pelo que foi apurado, Janine era também obrigada à prestação de serviços sexuais aos demais trabalhadores.

Jeferson e Janine foram vítimas de uma relação social que tende a desconhecer limites à sua própria lógica. A lógica é estrita, qual seja, reproduzir a si mesmo. Não há qualquer maniqueísmo nessas afirmaçoes, nem deve haver, caso se queira apreender a natureza do fenômeno aqui analisado. Muitas vezes os capitalistas são pessoas cordiais e honestas, enquadradas no padrão ético e moral almejado na nossa sociedade. Ocorre que, conforme declarou o proprietário da lavoura de tomate onde Jeferson era submetido à condição análoga à escrava, após a fiscalização ele percebera a gravidade da situação à qual estavam submetidos os trabalhadores, mas que até então ele "só via os tomates".

Ao contrário do que se poderia supor, as condições subumanas impostas aos trabalhadores não se restringem aos confins do país. Na verdade, a condição análoga à escrava é fenômeno flagrado em todas as regiões do Brasil, como evidenciam os dados do MTE (entre 2008 e 2011, houve resgates em 23 estados). Em julho de 2013 tramitavam ações penais com a participação do MPF, referentes a trabalho análogo ao escravo, em 25 estados$^{8}$.

\footnotetext{
${ }^{8}$ Os dados concernentes à atuação do MPF apresentados neste texto foram disponibilizados pela própria instituição na página: http://www.transparencia.mpf.mp.br/atuacao-funcional/mapa-atuacao.
}

Brasiliana - Journal for Brazilian Studies. Vol. 2, n.2 (Nov 2013). ISSN 2245-4373. 
Do mesmo modo, o fenômeno não se restringe à agropecuária, apesar da herança do latifúndio escravocrata contribuir para a alta incidência no setor. No total de flagrantes no Brasil, de 2003 até o final de 2011, constam pecuária, desmatamento, e lavouras, mas também atividades diretamente integradas à indústria, como carvão e reflorestamento. Além disso, há casos na construção civil (28 resgates apenas em 2011), confecções (10 resgates em 2010 e 2011), pedreiras, hotéis (CPT, 2011). Das cinco operações com maior número de trabalhadores resgatados em 2012 no país, três foram em cidades, incluindo a maior delas, numa siderúrgica.

Os flagrantes são comuns no setor de confecções de roupas. Nos últimos anos houve resgates de empregados que trabalhavam para a Zara, C\&A, Marisa, Pernambucanas, GAP, dentre outras grandes marcas nacionais e internacionais. Para ilustrar as condições de trabalho impostas, foi constatado em São Paulo, em 2010, que a rede de lojas Marisa estava diretamente articulada à exploração criminosa de 16 bolivianos e 1 peruano, endividados, sem carteira assinada, alojados em local com instalações elétricas expostas e extintores vencidos ao lado de tecidos; as jornadas de trabalho começavam às $7 \mathrm{~h}$ e chegavam até às $21 \mathrm{~h}$ : “Em apenas um cômodo nos fundos de um dos imóveis, construído para ser uma cozinha, sete pessoas dormiam em três beliches e uma cama avulsa. Infiltrações, umidade excessiva, falta de circulação de ar, mau cheiro e banheiros precários completavam o cenário de incorreções. Não havia separação adequada das diversas famílias alojadas na mesma construção" (Hashizume, 2010).

O setor de confecções evidencia que parece haver uma relação direta entre o crescimento das grandes marcas e a depredação da força de trabalho. A Collins, por exemplo, uma das que mais crescem no país, aumentou seu número de lojas de 20, em 2004, para 87, em 2009. Enquanto isso contratou trabalhadores, entre janeiro de 2009 a junho de 2010, por 78 oficinas irregulares, que produziram mais de 1,8 milhão de peças sem que 
qualquer empregado tivesse seu contrato de trabalho formalizado. Nesse processo, a empresa teria sonegado mais de $\mathrm{R} \$ 137,2$ milhões em FGTS e aproximadamente $\mathrm{R} \$ 400$ mil do INSS (Pyl, 2011).

A incidência do trabalho análogo ao escravo também não discrimina porte do capital, contemplando de pequenos empresários, a grandes grifes internacionais, passando pelo maior empresário da soja do Brasil (Erai Maggi, o "rei da soja" (Lambranho, 2010)), gigantes da produção de álcool e açúcar, como o grupo J Pessoa e Cosan, um dos maiores grupos de usinas de álcool do mundo.

Umas das maiores construtoras do país também tem se notabilizado pelos flagrantes de trabalho análogo ao escravo em diferentes estados do Brasil. A MRV cresceu com o programa "Minha casa, minha vida", do governo federal. Enquanto depredava sua força de trabalho, a MRV foi a construtora que mais cresceu no Brasil, conforme ranking do setor ${ }^{9}$. Com ascensão exponencial, figurou pela primeira vez em 2008, na $24^{a}$ posição, e atingiu posição de sétima maior construtora do país em 2012.

Além de poder atentar diretamente contra a liberdade individual (apesar de não haver, em geral, tal necessidade), a compulsão do capital ameaça a saúde dos trabalhadores, dignidade, segurança, e, inclusive, desconhece o limite físico do próprio elemento que lhe sustenta. Segundo Silva (2006), a vida útil dos trabalhadores no corte de cana nas décadas de 1990 e 2000 girava entre 10 e 15 anos $^{10}$, ou seja, menor do que os supramencionados 20 anos de produtividade dos trabalhadores escravos do século XIX.

Assim, são verificadas no assalariamento condições de trabalho semelhantes às de outras relações de produção pretéritas, especificamente, idênticas quando não piores, àquelas vigentes na escravidão voltada para a produção mercantil, como o modelo que

\footnotetext{
${ }^{9}$ Dados obtidos em: www.cbicdados.com.br/media/anexos/tabela_10.A.01.xlsx.

${ }^{10}$ Segundo a pastoral do imigrante, entre 2004 e 2007 teriam ocorrido 21 mortes de cortadores de cana por excesso de esforço durante o trabalho (Silva, 2006).
}

Brasiliana - Journal for Brazilian Studies. Vol. 2, n.2 (Nov 2013). ISSN 2245-4373. 
por séculos perdurou no Brasil. Como entender a sobrevida de abrigos em barracos de lona preta, falta de água potável, banheiro e local para refeições, mortes por exaustão, risco de morte por exposição a produtos nocivos? Sequer é possível comparar o assalariamento com a maioria dos padrões de uso da força de trabalho vigentes em outras sociedades, pois estes últimos eram geralmente desvinculados da lógica da reprodução ampliada do excedente (onde predomina o valor de uso, ao invés do valor de troca [Marx, 2002]), não engendrando necessariamente a exploração extrema das classes dominadas. A condição análoga à escrava é uma potencialidade do assalariamento sob a égide do capital.

Em que pese haver substanciais diferenças entre os capitalismos (por conta das diferentes trajetórias que impuseram limites externos à relação), trabalho análogo ao escravo tem sido detectado em diversos países do mundo, inclusive nações ricas, como os Estados Unidos, França e Itália, ou em amplo desenvolvimento capitalista, caso da China ${ }^{11}$. No Brasil, o fenômeno do trabalho análogo ao escravo é também vinculado ao padrão específico de desenvolvimento do nosso capitalismo retardatário, à tradição autoritária tributária do escravismo típico e à pessoalização das relações sociais típica da nossa cultura, mesmo aquelas que a princípio seriam impessoais (como o mercado), conforme identificado por Sérgio Buarque de Holanda (1995). Nesse terreno, são férteis as falsas promessas de bom emprego, a crença na dívida contraída, nas boas intenções do "gato", que o salário um dia será pago, que o trabalho é ruim, mas não se pode deixá-lo...

\footnotetext{
${ }^{11}$ Não se está aqui sugerindo qualquer espécie de retomada de interpretações restritas de qualquer lei da pauperrização da classe trabalhadora. Padrões de distribuição de renda e condições de trabalho conquistadas em algumas sociedades capitalistas não podem ser desconhecidos. A questão é simplesmente entender que esses avanços não estão inscritos na lógica da relação, a não ser em situações excepcionais de escassez de força de trabalho - a tendência, pelo contrário, é que o capital crie seu próprio exército industrial de reserva.
}

Brasiliana - Journal for Brazilian Studies. Vol. 2, n.2 (Nov 2013). ISSN 2245-4373. 
Ocorre que, no Brasil, a relação de assalariamento possui um limite externo prescrito. Caso seja transgredido esse limite, o Estado desconhece (e desfaz) a relação. É o que acontece quando constada a tão mencionada submissão de trabalhador à condição análoga à escrava.

\section{Limites da relação}

No Brasil, o Estado instituiu um limite (externo) prescrito para a existência da própria relação de trabalho assalariado ${ }^{12}$. Não se trata de regras a serem seguidas no interior da relação de emprego, mas de um limite à própria relação, sendo que o desrespeito desse limiar elimina o reconhecimento pelo Estado da possibilidade de assalariamento. Esse limite está expresso no artigo 149 do código penal ${ }^{13}$. Caso seja detectada sua transgressão, é desfeita a relação:

Reduzir alguém a condição análoga à de escravo, quer submetendo-o a trabalhos forçados ou a jornada exaustiva, quer sujeitando-o a condições degradantes de trabalho, quer restringindo, por qualquer meio, sua locomoção em razão de dívida contraída com o empregador ou preposto: (grifos nossos) $\S 1$ o nas mesmas penas incorre quem: I - cerceia o uso de qualquer meio de transporte por parte do trabalhador, com o fim de retê-lo no local de trabalho; II - mantém vigilância ostensiva no local de trabalho

\footnotetext{
${ }^{12}$ Afirmar que o limite é externo não significa que este é imposto por agente estranho à relação (no caso, o Estado). É externo porque se trata se intervenção que não é inerente ao trabalho assalariado. O Estado é agente que necessariamente integra a relação de emprego, pois é ele que contribui para instituir e garante a propriedade privada. Não existe trabalho assalariado sem Estado. Todavia, pelo fato de não ser monolítico, essa mesma instituição pode propor um limite que, a priori (por natureza), a relação não contempla.

13 O texto apesentado pode se tornar apenas uma redação, alterada em 2003, mas por enquanto tem sido hegemonicamente interpretada literalmente nas diversas instâncias e poderes do Estado.
}

Brasiliana - Journal for Brazilian Studies. Vol. 2, n.2 (Nov 2013). ISSN 2245-4373. 
ou se apodera de documentos ou objetos pessoais do trabalhador, com o fim de retê-lo no local de trabalho.

Desse modo, constitui crime no quadro jurídico brasileiro a submissão de outrem a trabalho através de coerção individual direta, seja mediante trabalho forçado, retenção de documentos, manutenção de vigilância no local de trabalho, restrição da locomoção por contra de dívida contraída; cerceamento do uso de meio de transporte por parte do trabalhador, com o fim de retê-lo no local de trabalho.

A proibição do trabalho forçado é comum a qualquer país capitalista que preveja a liberdade e igualdade formal entre os indivíduos. As Convenções da Organização Internacional do Trabalho (OIT) 29 (de 1930) e 105 (de 1957) têm previsões expressas de combate a tal prática: “'trabalho forçado ou obrigatório' compreenderá todo trabalho ou serviço exigido de uma pessoa sob a ameaça de sanção e para o qual não se tenha oferecido espontaneamente".

No Brasil, o trabalho obtido a partir de coação individual direta geralmente ocorre com base em mecanismos criados pelo empregador/preposto/intermediário de endividamento do trabalhador (mesmo que enganoso, desde que a vítima acredite), quando este último é expressamente coagido a permanecer em atividade para quitar o pretenso débito, ou se vê moralmente obrigado a continuar trabalhando independentemente as condições oferecidas para saldar o déficit. São casos em que se enquadram na servidão por dívida, como os exemplos dos bolivianos. Estratégia comum do capital para obter a servidão por dívida é mobilizar a força de trabalho entre diferentes localidades, dificultando seu deslocamento para sua cidade de origem e induzindo (ou deixando como única opção) o trabalhador a consumir os itens necessários à sua reprodução física em 
estabelecimento próprio ou credenciado, no qual a pretensa dívida é eternizada. Esse sistema de endividamento conhecido é como barracão ou truck sistem.

Contudo, há um aspecto particular, mas fundamental no artigo 149 do código penal brasileiro: o conceito de trabalho degradante como caracterizador, per si, do trabalho análogo ao escravo. Esse conceito (assim como o de jornada exaustiva), por independer da intencionalidade do capitalista singular, transcende o aspecto coercitivo direto impingido ao trabalho, atingindo a essência do aspecto coercitivo imposto ao trabalho no capitalismo. Conforme já indicado, o aspecto determinante do assalariamento é a dupla liberdade que obriga o trabalhador a vender sua força de trabalho. A coerção do capitalista individual pode existir nas relações contemporâneas análogas à de escravo, contudo, com o conceito de trabalho degradante essa coerção individual deixa de ser necessária para a configuração da analogia à escravidão. A coerção do mercado de trabalho é a coerção específica do modo de produção vigente e é precisamente isso que o artigo 149 incorpora, ao considerar condições de uso desumanas da força de trabalho como crime de redução à situação análoga à escravidão. É a coerção coletiva do capital (via mercado de trabalho) que viabiliza e está sempre presente na submissão de trabalhadores à água envenenada por agrotóxicos, aos salários atrasados, aos alojamentos de lona preta, à ausência de banheiros, à inexistência de locais para refeição, à retenção dos salários, fornecimento de comida estragada, jornadas intermináveis, enfim, submete trabalhadores a condições que seriam próprias do que poderíamos chamar de escravismo típico.

Destarte, além dos limites presumíveis (coação direta) prescritos pelo Estado (próprios da liberdade formal normalmente contemplada pelos Estados capitalistas), há um limite qualitativo ao uso da força de trabalho no Brasil (que limita as consequências da liberdade frente aos meios de produção).

Essas considerações não derivam de uma interpretação particular ou da tentativa de descoberta de uma interpretação verdadeira da norma, como se alguma existisse. Isso seria 
fetichizar a lei, desconhecendo que esta nada mais é do que uma relação social. Muito pelo contrário, nossas considerações derivam da intepretação majoritária que o Estado brasileiro tem dado ao art. 149 do Código Penal, constituindo, por conseguinte, a regra hegemonicamente em vigor.

Tem prevalecido, nas últimas décadas, a interpretação de que degradância, per si, configura trabalho análogo ao escravo (esteja ela acompanhada ou não das demais hipóteses previstas no art. 149). Por isso é possível dizer que a lei está contemplando a coerção coletiva do capital via mercado de trabalho. Essa é a interpretação hegemônica no MTE, que é o aparelho de Estado que efetua o resgate, ou seja, representa diretamente o Estado quando a relação é desfeita. Ela tem encontrado guarida no MPT e na JT. As deliberações da CONATRAE (Comissão Nacional Para Erradicação do Trabalho Escravo), que expressa a definição abraçada pelas direções das instituições, e contribui para homogeneização das ações dos seus agentes, corroboram esse entendimento.

Mas a disputa pelo quadro jurídico sobre o art. 149 é intensa, como veremos à frente. O quadro jurídico é o modo como o Estado efetivamente interpreta as normas, por hora prevalecendo a literalidade do artigo, que apresenta a degradância como condição suficiente para caracterização da condição análoga à escrava. Contudo, agentes no interior do próprio Estado defendem a interpretação de que só haveria condição análoga com a coerção individual direta do capitalista.

Também conceitualmente (para além das disputas do chamado campo jurídico) há lacunas sobre a definição do fenômeno, tarefa fundamental não apenas do ponto de vista científico, mas também pelos impactos políticos que a definição do fenômeno engendra.

Já há décadas são estudadas as formas de trabalho que se assemelham ao escravismo anterior à lei áurea. Cerqueira e Figueira (2008) demonstram que autores como José de Souza Martins, Fernando Henrique Cardoso, Otavio Ianni, entre outros, já estudavam a problemática do trabalho obtido sob pretexto de dívida, tanto no norte, quanto no nordeste 
do Brasil. O fenômeno era denominado pelos autores como "semi-escravidão", trabalho "semi-servil", "trabalho sob coerção", imobilização da força de trabalho, ou mesmo "escravidão". Cerqueira e Figueira (2008) vão se referir ao fenômeno como escravidão contemporânea ou escravidão.

\section{Escravidão pré-lei áurea e trabalho análogo ao escravo}

O trabalho análogo ao escravo é fenômeno trágico disseminado no nosso capitalismo. Contudo, é efetivamente distinto da relação existente na escravidão típica, padrão vigente nas relações de produção no Brasil até fins do século XIX. A distinção conceitual entre os fenômenos, corolário da diferença real entre os mesmos, é essencial não apenas para a apreensão da realidade, bem como para o profícuo enfrentamento político do problema.

Muitos estudiosos e engajados, sedentos por afirmar a injustiça e a crueldade das condições degradantes de trabalho, tratam o trabalho análogo ao escravo e o trabalho escravo típico como se fossem a mesma coisa. Tal postura, apesar de chocar e mobilizar mais rapidamente os observadores menos atentos (o senso comum), incorre em duplo equívoco (um conceitual e outro político), fomentando, inclusive, fortes obstáculos ao combate do trabalho análogo ao escravo.

O trabalho escravo típico era política de Estado, previsto em lei e mantido sob coerção direta do proprietário e/ou dos aparelhos repressivos estatais. O ser humano, e não a força de trabalho, era a própria mercadoria. Não havia exército industrial de reserva e o controle direto de cada trabalhador era fundamental para a produção do excedente. As condições degradantes de trabalho eram corolário da coação direta e legalmente estabelecida entre produtores e proprietários. 
O trabalho escravo é formalmente proibido pelo Estado no Brasil contemporâneo. Os trabalhadores não são eles mesmos a mercadoria, não sendo vendidos no mercado. Em geral, eles estão submetidos a condições degradantes sem que haja exercício de violência sobre eles. De fato, também como heranças da escravidão típica e do perfil cultural do nosso país, são verificadas diversas modalidades de coerção individual dissimulada (ou mesmo expressas) dos empregadores sobre os trabalhadores, especialmente através do emprego de dispositivos de endividamento, constituindo a servidão por dívida. Contudo, o trabalho análogo ao escravo é uma potencialidade de qualquer capitalismo sem regulação, pois, por natureza, o capital objetiva compulsivamente o lucro no bojo de uma relação (o assalariamento) que envolve agentes estruturalmente díspares.

Desse modo, equiparar conceitualmente trabalho escravo e trabalho análogo ao escravo é um profundo equívoco, pois abstrai a natureza específica do fenômeno contemporâneo, qual seja, a operação da coação do mercado (o moinho satânico de Polanyi (2000)) sobre o trabalho como agente de imposição de condições de uso da força de trabalho iguais àquelas vigentes em outros modos de produção. Em muitos casos, ocorrem condições piores do que à dos escravos, pois o exército industrial de reserva permite a reposição sem custos do trabalhador (na escravidão típica a reposição dependia da compra de novo escravo, muitas vezes um significativo investimento).

Se do ponto de vista conceitual é um erro considerar que o trabalho análogo ao escravo idêntico ao trabalho escravo, do ponto de vista político as repercussões são ainda piores, pois tal confusão fornece argumento ao capital na sua tentativa constante de deslegitimar a ação de combate ao fenômeno. O capital justamente argumenta reiteradamente que o trabalho degradante não é igual ao escravo, pois os trabalhadores não são acorrentados (por exemplo), com o objetivo de afrontar a ação estatal contra a exploração desmedida do trabalho. Ocorre que, de fato, o trabalho degradante não é 
escravo no sentido literal. Por isso, a insistência nessa homologia enfraquece o combate ao crime. É análogo, pois são as mesmas condições, mas com base em outros mecanismos de coerção. Isso não torna o fato menos grave, pelo contrário, torna o fenômeno mais cruel, pois a coerção impessoal do mercado sugere que o trabalhador aceita a degradância por opção, pois pretensamente livre.

É o Estado que garante a existência da propriedade privada, por conseguinte, viabiliza o assalariamento e a reprodução do capital. Portanto, se o capital só existe com a intervenção do Estado, seguir parâmetros elementares propostos por esse mesmo Estado, que preservem a vida e a dignidade do trabalho (que, por "acaso", reproduz o capital) é o mínimo que se pode esperar como justificativa para a existência do próprio monopólio social. Do contrário, se torna difícil até mesmo dissimular a tirania que por natureza a relação social denominada capital institui.

\section{Trabalho análogo ao escravo: disputas na regulação do Estado}

Jeferson e Janine foram resgatados pelo Estado brasileiro através do Grupo Especial de Fiscalização Móvel (GEFM) do MTE, que conta com a participação do MPT e da Polícia Federal. Jeferson e Janine foram dois dos aproximadamente 44 mil trabalhadores resgatados pelo Estado em situação análoga à de escravos nos últimos 18 anos, desde que houve a institucionalização do Grupo Executivo de Repressão ao Trabalho Forçado (GERTRAF) e do GEFM.

Quando do resgate, os trabalhadores têm suas carteiras assinadas, seus direitos pecuniários pagos e são enviados à terra natal, caso assim desejem, no caso de imigrantes. Eles recebem seus salários atrasados e demais direitos pecuniários previstos no quadro jurídico e são devolvidos aos familiares. Além disso, os empregadores sofrem as autuações (multas) do MTE, podendo ser acionadas civilmente pelo MPT, na JT (pedindo pagamento 
de indenizações por dano moral coletivo e dos direitos trabalhistas às vítimas), e criminalmente pelo MPF, na JF.

Há diferentes especulações sobre o número de trabalhadores em condição análoga à escrava no Brasil ${ }^{14}$. Contudo, como, por natureza, essa a condição não é publicizada pelo capitalista, pelo contrário, se há algum interesse é justamente de que o fenômeno seja encoberto, os casos só aparecem a partir de denúncias, e apenas se comprovam quando há fiscalização. Ocorre que o trabalho análogo ao escravo é combatido por um número extremamente reduzido de agentes de Estado ${ }^{15}$, o que torna ainda mais difícil mensurá-lo. Segundo a CPT (2011), aproximadamente 37\% das denúncias efetuadas por ela foram fiscalizadas, em média, entre os anos de 2003 e 2011.

Haver mais ou menos resgates não necessariamente significa, per si, maior incidência de trabalho análogo ao escravo em determinado local ou região. Acontece que a fiscalização do MTE tradicionalmente concilia com a ilegalidade (Filgueiras, 2012), mas tem mudado e se tornado mais impositiva em todos os aspectos ${ }^{16}$. Isso repercute no combate ao trabalho análogo ao escravo, de modo que situações provavelmente idênticas antes verificadas, só agora são punidas.

Em que pese a difícil mensuração, é possível inferir, conforme já mencionado, que o trabalho análogo ao escravo é fenômeno que atinge todo o país. Há flagrantes de analogia à escravidão em todas as cinco regiões do Brasil em diversos anos. Ademais, a maior incidência do trabalho análogo ao escravo parece manter relações com as conjunturas de

\footnotetext{
${ }^{14}$ Para a CPT, por exemplo, o número de trabalhadores poderia atingir 40 mil (DIAP, 2010).

${ }^{15} \mathrm{O}$ número de fiscais, para fiscalizar todo o mercado de trabalho no país, sequer consegue se manter, sendo hoje 300 a menos do que em 1990, quando havia 3100. Ocorre que a fiscalização abarca todos os aspectos da relação de emprego, o que inclui toda sorte de inspeção com base no universo de empregadores no país. Para o combate ao trabalho análogo ao escravo há apenas 4 grupos exclusivos, e alguns fiscais em todo o Brasil que se propõem a fazêlo, quando há denúncia.

${ }^{16}$ Apesar de contar com número de fiscais decrescente ao longo dos últimos anos, o MTE mais tem crescido substancialmente o número de autuações e de interdições desde o final da década passada.
}

Brasiliana - Journal for Brazilian Studies. Vol. 2, n.2 (Nov 2013). ISSN 2245-4373. 
acumulação do capital. Com o atual aquecimento do mercado de trabalho, por exemplo, há maior uso de jornada exaustiva e condições degradantes de trabalho, especialmente pela importação de força de trabalho nacional ou estrangeira (construção civil e confecções são os ramos mais notórios).

Além dos limites da própria fiscalização do MTE, o combate ao trabalho análogo ao escravo encontra outros duros obstáculos. Mesmo dentre os agentes de Estado existe resistência ao reconhecimento da existência da situação e à sanção dos responsáveis, engendrando uma disputa permanente pelo quadro jurídico concernente ao artigo 149 do $\mathrm{CP}$. Isso acontece tanto nas instituições de vigilância do direito do trabalho (MPT, MTE, JT), quantos nos demais órgãos que detêm competência relativamente ao referido crime (JF, MPF e PF) $)^{17}$.

No convívio cotidiano, muitos servidores apresentam explicitamente posições do tipo: "o trabalhador não estava amarrado", "ele poderia fugir", que "eu também já fui pobre", "a situação é ruim, mas é melhor do que não ter emprego". Mas essas posturas, mais ou menos explícitas, aparecem também formalmente. Dentre vários episódios, numa denúncia penal envolvendo um juiz do estado do Maranhão, a justiça estadual negou a ação com base no seguinte argumento:

“Sucede que o crime em espécie exige representativa submissão do sujeito passivo ao poder do agente, suprindo o status libertatis, posto que apenas desta forma anula-se por completo a liberdade de escolha da vítima, a qual é forçada a sujeitar-se a uma situação que atenta contra a sua dignidade" e

\footnotetext{
${ }^{17}$ Desde 2006, com base em acórdão do STF, tem sido hegemônico o entendimento de que a JF é instância responsável pelos julgamentos referentes ao crime de trabalho análogo ao escravo, em que pese a resistência ainda reinante entre os empregadores em aceitar tal jurisdição, vide reiterados pedidos de incompetência dos tribunais federais que ainda hoje são formulados pelas empresas. MPF e PF, por conseguinte, detêm suas atribuições concernentes aos casos.
}

Brasiliana - Journal for Brazilian Studies. Vol. 2, n.2 (Nov 2013). ISSN 2245-4373. 
que "há de se convir que o trato da vida envolto a uma fazenda é traçada com singelos modos de viver, o que não podem (sic) ser confundidos com condições degradantes de vida" (Pyl, 2009).

Em recente decisão (2013) concernente a episódio no qual trabalhadores cuidavam de um zoológico, alojados em barracão de lona, sentenciou um Juiz Federal. "não há evidências de que os trabalhadores, embora submetidos a condições de trabalho e moradia degradantes, não pudessem abandonar o local no momento em que quisessem". Conclui que não há crime, que só ocorreria se demonstrada "privação de liberdade, isto é, que esteja claro que a vítima só se sujeita ao trabalho porque é impedida de deixar o local, em razão de coação por parte do agente" (Processo 31479-81.2012.4.01.3700).

Como citado na introdução o presente texto, até um ex-presidente do TST segue essa linha:

No Brasil, a lei penal é inadequada para a responsabilização dos infratores. Falta clareza, também, ao qualificar como crime de condição análoga à escravidão a submissão do empregado a uma jornada exaustiva ou em situação degradante. A legislação penal brasileira está em descompasso com o conceito universal de trabalho escravo, que considera como tal os casos em que o trabalhador tem sua liberdade de ir e vir comprometida por força de uma opressão física ou psicológica. Isso deve ser punido de forma severa. Não conheço um caso de condenação criminal por trabalho forçado no Brasil. O Executivo pode e deve resolver essa questão. Há um projeto de lei antigo, já aprovado no Senado, que está na Câmara, que resolve essa questão, extirpando do conceito de trabalho escravo a ideia de jornada exaustiva e em condições degradantes (Dalazen, 2012). 
Ele não está sozinho na Justiça do Trabalho. Há juízes e tribunais que requerem a restrição de liberdade como condição necessária para caracterização do trabalho análogo ao escravo, como notaram Rezende e Silveira (2013). Em acórdão recente (13/06/2012), o TRT 10 decidiu que:

É preciso considerar que a caracterização do trabalho degradante depende de fatores subjetivos como por exemplo o constrangimento físico ou moral, a limitação da liberdade de ir e vir, a retenção de salários, a existência concreta de qualquer ameaça ou constrangimento ilegal, a submissão a trabalhos forçados, regime de servidão por dívida devidamente documentado (Processo: 00777-2011-020-10-00-5-ReeNecRO)

Mesmo assim, ao longo dos últimos anos tem prevalecido o conceito literal do artigo 149 nos tribunais superiores do Brasil (TST, STJ e STF), imputando à degradância como condição suficiente para caracterização do crime. Isso é indicado por pesquisa que efetuamos na jurisprudência do STF e SJT (no TST, para ilustrar, ver Processo 6110007.2004.5.08.0118).

Analisamos todos os acórdãos dos dois tribunais sobre trabalho análogo ao escravo desde a década de 1990. Nos últimos anos, tanto o SJT, quanto o STF, têm se posicionado reiteradamente pela degradância como suficiente para o crime:

Para configuração do crime do art. 149 do Código Penal, não é necessário que se prove a coação física da liberdade de ir e vir ou mesmo o cerceamento da liberdade de locomoção, bastando a submissão da vítima 
"a trabalhos forçados ou a jornada exaustiva" ou "a condições degradantes de trabalho", condutas alternativas previstas no tipo penal (inquérito 3412, acórdão do STF de março de 2012).

Todavia, as composições dos votos são quase sempre muito disputadas. Na mais recente das dez decisões do STF sobre o tema, datada de 11 de dezembro de 2012, o relator, Gilmar Mendes, deixou expressa a sua posição:

Não fosse a questão do armazém, eu, inclusive, daria a ordem pretendida, porque só o apontamento de más condições, me parece que isso tem de ser resolvido na esfera exclusivamente trabalhista. Talvez, se se fizer o exame das condições de trabalho, aqui na garagem do Supremo Tribunal Federal, os critérios hoje utilizados pelo Ministério Público do Trabalho ou, na própria Procuradoria-Geral da República, certamente, vai-se encontrar essas condições análogas à de escravo, a não ter um armário adequado para que o empregado guarde seus pertences. (...) eu já tive a oportunidade de ressaltar que muitas dessas denúncias são feitas por pessoas que nunca viram um quintal, que não conhecem, portanto, nenhuma propriedade rural, nem as condições que, em geral, existem nessas propriedades rurais, por isso que eu sou muito crítico dessa prática.

Atualmente os acórdãos do STF são decididos por diferença mínima de votos, com alguns favoráveis militantemente apenas à restrição de liberdade como caracterização do crime, incluindo não apenas Gilmar Mendes, notoriamente ligado ao PSDB, mas membros 
indicados pelo autointitulado partido dos trabalhadores, como seu ex advogado, Dias Toffoli.

Ademais, mesmo com a prevalência da interpretação da coerção coletiva, há outros desafios ao combate ao trabalho análogo ao escravo. Muitos trabalhadores retornam às condições de trabalho degradantes algum tempo depois do resgate, pois inexistem mecanismos estatais suficientes que lhes dêem suporte. Destaque-se, contudo, a modalidade do seguro desemprego 'Especial para o Resgatado', benefício iniciado em 2002. O trabalhador resgatado da condição análoga à de escravo tem direito a receber três parcelas do seguro-desemprego no valor de um salário mínimo cada. Recentemente também tem sido promovidos pelo MTE cursos de qualificação para os trabalhadores resgatados.

O combate do trabalho análogo ao escravo, no que concerne às instituições de vigilância de direito do trabalho e órgãos com competência penal, contudo, é uma política pública pelo lado da demanda, ou seja, busca incentivar os capitalistas a tratar com dignidade mínima sua força de trabalho para não incidir no crime. Porém, os capitalistas pouco temem esses incentivos.

Nas ações há raras prisões em flagrante, pois o MPF e DPF, que detêm prerrogativa criminal sobre os casos, raramente se propõem a participar ${ }^{18}$. As condenações criminais na Justiça Federal, quando ocorrem, são normalmente transformadas em penas alternativas. As multas aplicadas pelo MTE, apesar de incomodar (cada infração concernente ao meio ambiente de trabalho implica multa de um a seis mil reais, aproximadamente), não

\footnotetext{
${ }^{18}$ É importante salientar que a participação do MPF no combate parece ser crescente. Em julho de 2013 estavam cadastradas 479 ações penais concernentes sobre trabalho análogo ao escravo oferecidas pelo MPF. Tendo em vista que o número de resgates já efetuados pela fiscalização do trabalho até o final de 2012 foi de aproximadamente 1700 , temos um percentual de repercussão criminal não desprezível.
}

Brasiliana - Journal for Brazilian Studies. Vol. 2, n.2 (Nov 2013). ISSN 2245-4373. 
assustam. O MPT cada vez mais privilegia os TAC (Termo de Ajustamento de Conduta) nas ações, muitas vezes sem sequer inserir dano moral reparatório ${ }^{19}$.

Não por acaso, os casos de reincidência na prática criminosa são recorrentes ${ }^{20}$. $\mathrm{O}$ referido grupo sucroalcooleiro J pessoa, por exemplo, em dois anos foi flagrado quatro vezes mantendo trabalhadores em condições análogas às dos escravos "Ao todo, 1.468 pessoas foram libertadas de canaviais vinculados à empresa em diferentes estados do país: Mato Grosso do Sul, São Paulo e Rio de Janeiro". (Hashizume, 2010). As gigantes MRV e a Cosan, já citadas, também foram flagradas em oportunidades reiteradas submetendo trabalhadores à condição análoga à escravidão.

Como iniciativa de constrangimento ao capital, houve a criação pelo Poder Executivo, em 2004, de um cadastro onde figuram os empregadores flagrados infringindo o art.149, conhecido como "lista suja". O capitalista fica impedido de obter empréstimos em bancos oficiais. A lista é um incentivo relevante de incentivo ao capital, tanto assim que é recorrentemente combatida. Mais de metade dos processos que passaram pelo STJ contemplando a palavra "escravo", após, 2004, eram pedidos dos empregadores para retirada de seus nomes da lista suja, já questionada, sem sucesso, até no STF.

Um forte mecanismo de desincentivo ao uso desumano da força de trabalho é a Proposta de Emenda Constitucional (PEC) número 438, apresentada em 1999. Ela propõe nova redação ao Art. 243 da Constituição Federal, que trata do confisco de propriedades

\footnotetext{
${ }^{19}$ Assim como a fiscalização do MTE, no MPT as ações concernentes ao trabalho análogo ao escravo são mais impositivas do que sua postura padrão (ver Filgueiras (2012)), mas ainda assim são flexíveis, prevalecendo os TAC: "Embora a instituição ainda não disponha de um banco de dados informatizado, que disponibilize todos os números de sua atuação no combate ao trabalho análogo ao de escravo, dados divulgados em 2007 informaram que, no período de 2003 a 2006, o MPT firmou 253 termos de ajuste de conduta; ajuizou 206 ações civis públicas (...) em relação ao ano de 2009 revela que em todo o País foram inspecionados 566 estabelecimentos, de onde foram resgatados 3.571 trabalhadores mantidos em condições análogas à de escravo, sendo firmados 167 termos de ajuste de conduta e propostas 59 ações civis públicas e coletivas sobre o tema". (Ribeiro Silva, 2010, p. 182 e 183). Não raramente, como no acordão supracitado do TRT 10 (Processo: 00777-2011-020-10-00-5-ReeNecRO), a assinatura de TAC é utilizada como argumento, pela Justiça, para atenuar a gravidade da conduta das empresas.
}

${ }^{20}$ Ver, por exemplo, as reportagens de: Bacha (2010), Hashizume (2010), Lambranho (2010);

Brasiliana - Journal for Brazilian Studies. Vol. 2, n.2 (Nov 2013). ISSN 2245-4373. 
onde forem encontradas lavouras de psicotrópicas ilegais. A PEC estende a expropriação sem direito à indenização para casos de exploração do trabalho análoga à escravidão. A proposta define ainda que as propriedades confiscadas sejam destinadas ao assentamento de famílias para contribuir com a reforma agrária. Ela ainda precisa ser novamente aprovada na câmara, após votação em 2012 no senado, depois de muita resistência.

Vale ressaltar que o cerne da disputa em torno da referida PEC, durante todo seu processo de tramitação, reside justamente no conceito de trabalho análogo ao escravo. As forças do capital, por óbvio, lutam para restringir o conceito à coerção individual direta, retirando os limites às exploração do trabalho viabilizada pelo mercado de trabalho. A votação que aprovou a PEC na Câmara dos Deputados em 2012, por sinal, só aconteceu após acordo para posterior discussão do conceito ${ }^{21}$.

\section{Considerações Finais}

Este texto buscou demonstrar como o quadro jurídico vigente no Brasil prescreve um limite à existência do assalariamento. Trata-se de um limite externo à relação, que contempla a coerção específica do capitalismo, pois independe da coação individual do comprador da força de trabalho para se estabelecer.

Por natureza, o capital questiona e ataca tudo que considerar obstáculo ou simplesmente entrave à sua reprodução. A defesa da flexibilização do trabalho no Brasil nas últimas duas décadas é apenas mais uma evidência desse processo. A dignidade humana também é uma barreira à reprodução do capital, pois respeitá-la demanda dispêndio de recursos que não necessariamente implicarão retornos financeiros. O limite às condições do

\footnotetext{
${ }^{21}$ Por exemplo, ver reportagem: "Ruralistas tentam descaracterizar o que é trabalho escravo. PEC é aprovada por unanimidade na CCJ do Senado graças a acordo que prevê criação de grupo misto no Congresso para debater conceito. Manobra ameaça combate à prática" (PERES, 2013)
}

Brasiliana - Journal for Brazilian Studies. Vol. 2, n.2 (Nov 2013). ISSN 2245-4373. 
assalariamento só pode ser exógeno (seja através de intervenção subsidiária estatal, da organização coletiva dos trabalhadores, etc.), pois a própria relação não abarca inerentemente nenhum.

O limite ao trabalho assalariado prescrito pelo Estado no Brasil vem tentando ser efetivado através da ação de algumas instituições, mas o combate tem sido difícil em diversos aspectos. O próprio conceito de trabalho análogo ao escravo, na atuação das instituições do Estado, é alvo de disputa encardida, e, caso retroceda à necessidade de coerção física direta, retirará os limites às exploração do trabalho no âmbito do assalariamento, limitando-se apenas o trabalho por coerção direta, que por natureza não é típica, nem precisa ser rotineiramente empregado no capitalismo, dada a coação do mercado de trabalho.

A luta pelo conceito e o combate contra o trabalho análogo ao escravo é fundamental para a atenuação da exploração do trabalho e deve continuar a ser realizada. É preciso ter em mente, contudo, que por mais que o combate ao trabalho análogo ao escravo eventualmente avance, as condições degradantes não serão definitivamente eliminadas enquanto viger o atual modo de produção da riqueza social. Ainda assim, dada a imensa maleabilidade da relação social denominada capital, é efetivamente possível que sejam atingidos elevados níveis de controle ou mesmo interrupção, por algum período, da manifestação de condições de trabalho análogas à escravidão em formações sociais capitalistas.

\section{Referências}

Bacha, Rodrigo. Fazendeiros reincidem na escravidão e enganam até parentes. 30 de abril de 2010. Obtido em: http://www.reporterbrasil.org.br. 
Cerqueira, Gelba; Figueira, Ricardo. Introdução. Trabalho escravo contemporâneo no Brasil: contribuições para sua análise e denúncia. In: Cerqueira, Gelba; Figueira, Ricardo; Prado, Adonia; Costa, Célia Maria (Orgs.). Trabalho escravo contemporâneo no Brasil: contribuições para sua análise e denúncia. Rio de Janeiro, Editora UFRJ, 2008.

Dalazen, João Oreste. "Tudo mudou, exceto a legislação trabalhista". In Revista Consultor Jurídico, 15 de julho de 2012. Obtido em http://www.conjur.com.br/2012-jul-15/tudo-mudouexceto-legislacao-trabalhista-presidente-tst Acesso em: 01/06/2013.

DIAP. 'Trabalho escravo no Brasil pode atingir 40 mil pessoas, segundo CPT'. Agência DIAP, 14 de fevereiro de 2010. Obtido em 18/02/2010: http://www.diap.org.br/index.php/agencia-diap/12078-trabalho-escravo-no-brasil-podeatingir-40-mil-pessoas-segundo-cpt

CNI. Cento e uma propostas para modernizar as relações trabalhistas. 2012.

CPT. Campanha da CPT contra o trabalho escravo. Estatísticas em 31/12/2011. Obtido em: reporterbrasil.org.br/documentos/relatoriocpt2011.pdf. Acesso em 01/06/2013.

Filgueiras, Vitor. Estado e direito do trabalho no Brasil: regulação do emprego entre 1988 e 2008. Tese de doutorado. Salvador, UFBA, 2013.

Holanda, Sérgio Buarque. Raízes do Brasil. São Paulo: Companhia das Letras, 1995.

Hashizume, Maurício. Grupo J. Pessoa: mais de 1,4 mil libertados em quatro flagrantes: Empresa contesta fiscalização. 12 de abril de 2010. Obtido em: http://reporterbrasil.org.br/2010/04/grupo-j-pessoa-mais-de-1-4-mil-libertados-em-quatroflagrantes/

. 'Escravidão é flagrada em oficina de costura ligada à Marisa'. Repórter Brasil, 17 de março de 2010.2 Obtido em: http://www.reporterbrasil.org.br/exibe.php?id=1714\&name=Escravidão-é-flagrada-em -oficina-de-costura-ligada-à-Marisa

- 'Caso Cosan: aliciamento, dívidas e cortador de 17 anos'. Repórter Brasil, 20 de janeiro de 2010. Obtido em: Obtido em: http://www.reporterbrasil.org.br/exibe.php?id=1695 . 'Assentamento no Piauí simboliza limites do combate à escravidão'. Repórter Brasil, 4 de fevereiro de 2010. Obtido em: http://www.reporterbrasil.org.br/exibe.php?id=1700 
Lambranho, Lúcio. 'Ação de trabalho escravo contra "rei da soja" se arrasta. de abril de 2010'. Obtido em: http://congressoemf oco.ig.com. br/noticia. asp?cod_canal= $21 \&$ cod_publicacao $=32450$.

Marx, Karl. O capital: crítica da economia política. Rio de Janeiro, Civilização Brasileira, 2002.

OIT. Perfil dos principais atores envolvidos no trabalho escravo rural no Brasil / Organização Internacional do Trabalho. Brasilia: OIT, 2011

Peres, Cristiane. Ruralistas tentam descaracterizar o que é trabalho escravo. 27 de junho de 2013, obtido em http://www.trabalhoescravo.org.br/noticia/70.

Polanyi, Karl. A grande transformação: as origens de nossa época. Rio de Janeiro, Elsevier, 2000.

Pyl, Bianca; Hashizume, Maurício. 'CPT alerta para denúncias não fiscalizadas na Região Norte'. Repórter Brasil, 23 de fevereiro de 2010. Obtido em 24 de fevereiro de 2010: http://www.reporterbrasil.org.br/exibe.php?id=1708

. 'Tribunal rejeita denúncia e absolve juiz acusado de escravidão' Repórter Brasil. $1^{\circ}$ de dezembro de 2009. Obtido em: http://www.reporterbrasil.org.br/exibe.php?id=1676

. 'DPU ajuíza ação contra a Collins por trabalho escravo'. Repórter Brasil, 10 de maio de 2011. Obtido em: http://reporterbrasil.org.br/2011/05/dpu-ajuiza-acao-contra-a-collins-portrabalho-escravo/

Rezende „Maria José de; Rezende, Rita de Cássia. 'As dificuldades de erradicação do trabalho escravo no Brasil hoje e a exposição dos muitos desafios postos ao desenvolvimento humano'. In Nómadas. Revista Crítica de Ciencias Sociales y Jurídicas I Núm. Especial: América Latina (2013).

Ribeiro Silva, Marcelo. Trabalho análogo ao de escravo rural no Brasil do século XXI: novos contornos de um antigo problema. Dissertação de mestrado. Goiânia, UFG, 2010.

Silva, Maria Aparecida de Moraes. 'Morte e acidentes nas profundezas do "mar de cana" e dos laranjais paulistas'. São Paulo, INTERFACEHS, 2006. Obtido em 15 de maio de 2010 em: http://www.interfacehs.sp.senac.br/br/artigos.asp?ed=8\&cod_artigo=146 
Filgueiras, Vitor Araújo. Trabalho Análogo ao Escravo e o Limite da Relação de Emprego: Natureza e Disputa na Regulação do Estado.

Weber, Max. A ética protestante e o espírito do capitalismo. São Paulo. Pioneira Thomson Learning, 2003.

Brasiliana - Journal for Brazilian Studies. Vol. 2, n.2 (Nov 2013). ISSN 2245-4373. 